\section{SELECT COMMITTEE}

\section{NERC and Oceanography}

The Select Committee on Science and Technology has at last found someone who is prepared to say that fisheries research would be better in the charge of the Natural Environment Research Council. After first pleading the natural modesty that prevents NERC from claiming that it could do the job better than the Ministry of Agriculture, Professor M. J. Lighthill agreed last week that the advice of his oceanography and fisheries committee could probably be better implemented if NERC controlled the fisheries laboratories. Modestly backed by $\mathrm{Mr}$ R. J. H. Beverton and Mr D. J. Maclean, respectively secretary and deputy secretary of NERC, the professor gave the liveliest performance seen so far during the subcommittee's probing of the affairs of NERC.

The familiar theme of the size of NERC's empire arose after Professor Lighthill had agreed that the Government was right in 1965 to disregard the advice of the Trend Committee and give the new council responsibility for the National Institute of Oceanography. There has been no friction with the Admiralty because of the excellent coordination with naval oceanographers which his oceanography and fisheries committee makes possible. The navy is apparently very helpful when asked to cooperate.

Professor Lighthill was anxious to point out that his committee not only coordinates the oceanographic aspects of NERC's work but also takes very seriously its brief to give advice on matters of fisheries research to the Ministry of Agriculture, Fisheries and Food. $\mathrm{He}$ and his colleagues frequently visit Lowestoft, Aberdeen and the smaller laboratories when formulating their advice. But they evidently feel sometimes that their advice is not too well taken, for Professor Light. hill finally remarked that if all fisheries research was brought into NERC's sphere of responsibility, priorities might be different and organization better. His committee would like to see laboratories given better facilities, for example, larger tanks for studying fish behaviour, but the Fisheries Department cannot always give priorities of this sort. If NERC had fisheries research under its wing it would be able to meet the priorities.

So far NERC seems to be satisfied with the amount it has been able to spend on oceanography. The Council for Scientific Policy has been agreeably sympathetic to the need to expand the marine sciences, and in the past four years expenditure has doubled. The professor said this increase must continue if work such as coastal oceanography is to expand adequately.

Relations with industry are apparently excellent. The National Institute of Oceanography is a source of information for many sectors of the oceanography industry, and NERC is participating in various projects. With the British Aircraft Corporation it is developing a new kind of sonar apparatus, and Plessey is working with NERC on ocean data stations. In many cases industry and NERC ore each doing half of the work, but nobody was prepared to say that liaison with industry is sufficiently good that when NERC initiates a project with industrial potential industry will be adequately informed at an early stage. Mr Maclean would only say that he had seen a great improvement in the situation during the past two years.

When the subject of the recent white paper on marine science and technology was discussed, Mr Beverton and Professor Lighthill took pains to defend it in the face of Sir Harry Legge-Bourke's remark that many who had waited on tenterhooks for the report found it the biggest damp squib ever. NERC had been preparing its own survey which was incorporated into this report. The council will now work on and set out the scientific programme which was missing from the white paper.

\section{Parliament in Britain}

\section{Social Science Research Council}

THE council's budget for $1969-70$ is $£ 2.38$ million compared with $£ 509,000$ in $1966-67$. Mrs S. Williams, for the Department of Education and Science, said the 368 per cent increase in the council's budget from its start three years ago reflects the initial period of growth needed to establish the council. Allocations for specific disciplines are not predetermined, but, of

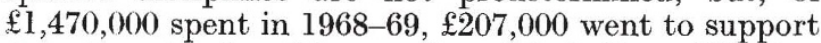
departments of sociology and social studies. (Written answer, May 5.)

\section{Doctors from Overseas}

T'He details of the nationalities of doctors employed in the hospitals in the Coventry hospital group, which were given by Mr Crossman, the Minister of Health and Social Security, give some indication of the dependence of the health service on foreign doctors. Of 266 doctors, 165 are British, the remainder come from overseas, especially Commonwealth countries and in particular the Indian subcontinent. Fifty of the doctors in the survey are Indian and seventeen Pakistani.

Mr Crossman also gave details of fires in British hospitals over the past five years. In 1963 there were 590 fires compared with 638 and 650 fires in 1966 and 1967. The ministry, no doubt concerned at the increase, now asks hospitals to hold at least two fire drills a year. (Written answers, May 5.)

\section{Long Range Weather Forecasting}

MR G. W. Reynolds, for the Ministry of Defence, said that the Meteorological Office is not taking part in the Barbados Oceanographic and Meteorological Experiment, which is a largely American affair. $\mathrm{Mr}$ Gresham Cooke claimed that the Americans, after putting a great deal of effort into the project, are coming to the conclusion that the Windward Islands and Barbados may be the centre of the atmospheric circulation in the Northern Hemisphere. Information about meteorological conditions in the area would therefore be crucial for long range weather forecasts. Mr Reynolds then said that Britain, together with other European countries, was and would be doing similar work in other parts of the North Atlantic. The Americans would receive reports of this work and we would receive reports of their work in the Barbados area.

Mr Reynolds declined to make a statement about the long-term future of the Roval Naval College at Green- 


\section{NUCLEAR REORGANIZATION}

\section{Evidence of BNDC}

NeITHer of the two companies which are to be the kernel of Britain's reshaped nuclear power industry yet has a licence from the Atomic Energy Authority for the promising steam generating heavy water reactor, which the industry is hoping to sell abroad. This is why the negotiations for the supply of an SGHWR to Greece in exchange for large quantities of Greek tobacco are being conducted by the AEA, rather than the company which is hoping to build the reactor (Nature, 222, 509; 1969). This surprisingly uncommercial situation was confirmed by Mr Hector McNeil, chairman of British Nuclear Design and Construction Limited, in evidence at the fourth public session last week of the House of Commons Select Committee looking into the reformed nuclear power industry. The committee was not entirely soothed by Mr McNeil's confidence that the licence will be fortheoming if the Greek deal goes through. Mr McNeil said the requirement was for a 300-350 MW station, and if BNDC wins the order it will need between twenty and twenty-five members of the design staff of the AEA. He told Mr David Ginsburg that BNDC is not in competition with the other half of the reshaped nuclear industry, the Nuclear Power Group, over the Greek contract, but if the tobacco deal is not negotiated then there will be bids from foreign companies.

Like many of his predecessors in the witness stand, Mr McNeil made plaintive noises about the refusal of the British electricity generating boards to build an SGHWR station, which is allegedly an obstacle to the SGHWR's export prospects. But the generating boards already have an embarrassing amount of spare capacity, and Mr MeNeil's complaint shows signs of wearing thin. Mr David Price suggested that the $100 \mathrm{MW}$ experimental SGHWR station at Winfrith goes some of the way to proving that the SGHWR works. $\mathrm{Mr}$ McNeil also wanted the already well-endowed generating boards to order two nuclear power stations each year-the level of ordering which is necessary if the two nuclear companies are to be kept going. But $\mathrm{Mr}$ McNeil showed no signs of agreeing with the 1967 recommendation of the Select Committce that there should be a single nuclear company. Rather he took pains to point out how beneficial was the competition between BNDC and TNPG for the Hartlepools contract, when $£ 250,000$ was probably all that decided in favour of BNDC in an $£ 80$ million contract. If TNPG had not been bidding, the BNDC price would have been higher. As it was, the BNDC price was the minimum it could afford, although he denied the suggestion of Mr Eric Lubbock that the Hartlepools bid was a loss leader.

Once again the attempt by TNPG to sell a nuclear power station to South Korea came under scrutiny. Although the Koreans have given a letter of intent to Westinghouse, TNPG is still hopeful of winning the contract because Westinghouse is having difficulty in arranging the loan for about 90 per cent of the cost of the station, which is one of the conditions of the deal. BNDC is involved because one of its shareholders, English Electric, has a letter of intent from Westinghouse for provision of the turbogenerators and a corresponding amount of credit. At last week's meeting of the committee, Mr Ghalib of TNPG thought that if the credit is forthcoming, TNPG will have lost its chance of winning the contract. Mr McNeil pointed out that Westinghouse has had other offers of credit from Europe, but $\mathrm{Mr}$ Lubbock still felt that the arrangement is unfair to TNPG.

In practice, this seems to be a time when British nuclear power companies are flirting again with the idea that they might be able to sell substantial amounts of nuclear power overseas. Their latest hope is a possibility of selling a reactor to Eastern Europe. wich. The college remains under review. (Oral and written answers, May 7.)

Foot and Mouth Disease

Mr C. Hughes, the Minister of Agriculture, said that the Government had paid $£ 150,000$ in special grants to farmers who suffered loss from foot and mouth disease during the early part of the 1967-68 epidemic. This money was paid as a $30 s$ grant for every $£ l$ collected by the National Farmers Union Appeal Fund. It was in addition to the $£ 26.5$ million paid in compensation for all animals slaughtered during the epidemic. (Written answer, May 7.)

\section{International Telex Exchange}

The Postmaster General, Mr Stonehouse, must by now be only too well aware that letters with $5 d$ stamps on them do not always arrive the day after being posted. A week never passes without examples of delays being brought to his notice. But the letter post is not the only Post Office activity subject to delay. $\mathrm{Mr}$ Stonehouse admitted that the London switchboard of the International Telex was now approximately five months behind schedule because contractors had failed to supply the $£ 112,000$ worth of equipment on time. The Post Office is also having problems recruiting the necessary switchboard operators. At present it has 372 but needs 456 and will need 528 later this year. (Written answer, May 8.)

Teachers' Pay

Mrs S. Wruldams, for the Department of Education and Science, said that she could not estimate how. many more university dons would be teaching in the universities as a result of the Prices and Incomes Board pay award. She said that discretionary payments and distinction awards would be pensionable. Miss A. Bacon said the minister would not refer school teachers' pay to the board. (Written answers, May 9.) Computer Aided Design

Dr J. Bray, for the Ministry of Technology, said that the five recommendations of the Computer Aided Design Committee which have not been adopted by the chemical plant industry were concerned with work of an advanced nature not immediately applicable to the industry. They did not at the time generate enough interest to warrant the placing of contracts by the ministry. The two projects that have been placed with industry following recommendations of the committee have cost $f 60,000$. Dr Bray said that the ministry's spending on computer aided design in the financial year ending March 31, 1969, was about £l.5 million. (Written answer, May 9.) 